\title{
Yazınsal Onomastik ve Çocuk Yazını Çevirisinde Kişi Adlarının Çevrilebilirliği Üzerine
}

\author{
Doç. Dr. Dilek Turan \\ Hacettepe Üniversitesi \\ Mütercim Tercümanlık Bölümü \\ dilekt@hacettepe.edu.tr
}

Öz

Çocuk yazını çevirisi, tüm dünyada olduğu gibi ülkemizde de önemli bir çalışma alanıdır. Ancak, çocuk yazını çevirisinde çevirmenler çeşitli sorunlarla karşılaşmaktadırlar. Ortaya çıkan sorunlardan bir tanesi de eserlerde yer alan kişi adlarının çevrilip çevrilmemesi veya nasıl çevrilmesi gerektiğidir. Çocuk yazını çevirisinde kişi adlarının anlam ve işlevleri ayrı bir önem taşır; çünkü isimler hikâyenin çocuk okur tarafından anlaşılmasında önemli rol oynar. Bu bağlamda onomastik (adbilim) ile çeviribilimin birlikte çalışması, çeviribilim için önemli bir yaklaşımdır. Onomastik, özel isimleri araştıran, isimleri köken bilgisi, tarihsel gelişme yönünden ve dil ve kültür sorunları açısından inceleyen bilimdir. Çeviri yazında özel isimler özellikle de kişi adları, çevirmeni bir seçim yapmak zorunda bırakır. Bu noktada çeviribilimin onomastik ve edebiyatbilim ile birlikte çalışması, çeviribilim açısından yeni bir yaklaşım sağlar. Bu disiplinlerarası çalışmanın önemini ortaya koymak için, bu çalışmada onomastik alanında yapılan çalışmalar incelendikten sonra, yazınsal onomastik alanı irdelenecek ve çocuk yazınından bir çeviri örneğindeki kişi adları incelenecektir. Bu incelemenin amacı, onomastik ile çeviribilimin disiplinlerarası çalışmalara sağlayacağı katkının ortaya konmasıdır.

Anahtar Kelimeler: Onomastik, özel isimler, kişi adları, çeviri stratejileri, çeviri çocuk yazını.

\section{Literary Onomastics and the Translatability of Personel Names in Translated Children's Literature}

\begin{abstract}
Children's literature is an important field of study in Turkey as around the world. However, translators encounter various problems when translating children's literature, for example, whether and how to translate personal names in children's literary works. In translated children's literature, the meaning and function of personal names are of special importance because personal names play a key role in the comprehensibility of a story by child readers. Thus, the collaboration of onomastic and translation studies is an important approach for translation studies. Onomastics is the science that studies proper nouns in terms of etymology, history, and linguistic and cultural problems. In translated literature,
\end{abstract}


proper nouns, especially personal names, force the translator to make a choice. Thus, the collaboration of translation studies with onomastics and literature provides a new approach for translation studies. To illustrate the importance of this interdisciplinary collaboration, this study first reviews existing studies in the field of onomastics and literary onomastics and then examines personal names in sample translated children's literature. The purpose of this examination is to reveal the contribution that onomastics and translation studies can provide to interdisciplinary studies.

Keywords: Onomastics, proper nouns, personal names, translation strategies, translated children's literature. 


\section{GİRIŞ}

Küreselleşmenin, yoğun kültür alışverişinin, son derece hızlı iletişim ağlarının ve yabancı dil ediniminin yaşandığı günümüz dünyasında, çeviri yaklaşımları tartışmasında onomastiğin (adbilim) çeviribilime sağlayacağı katkıyı irdelemek gerekir. Özellikle çeviri çocuk yazınında kişi adlarının aktarımı konusunda ortaya çıkan sorunlar ve çeviri yaklaşımı tartışması her zaman sürmüştür. Tartışmalar kaynak ve erek odaklı çeviri yaklaşımları çerçevesinde sürerken, bu çalışmada yazınsal onomastik alanının çevirmene yol gösterici olabileceği üzerinde durulacaktır. Onomastik yaklaşım, erek veya kaynak odaklılıktan çok, eserin çevirmeni nereye götürdüğü, özel isim - eser - okur - yazar etkileşiminin önemi konusunda çocuk yazını çevirmenine önemli ipuçları verebilir. Çeviri çocuk yazınında kişi adlarının çevirisine yoğunlaşacağımız bu çalışmada, çocuk yazınında kişi adlarının anlam ve işlevi, onomastik (adbilim) çerçevesinde incelenecektir.

İsim verme geleneği, çok eskilere dayanan ve her kültürde farklı biçimlerde (dini, toplumsal) süren bir gelenektir. İsimler, içinde yaşanılan coğrafyaya, kültüre göre değişim gösterdiğinden, her ülkede farklılık göstermektedir. İsim verme geleneği, ülkelerin edebiyatlarına, dolayısıyla yazınsal metinlere de yansımaktadır. Söz konusu yazın çevirisi olduğunda ise, kişi adları farklı bir boyut kazanır. Yazın çevirisinde kişi adlarının çevirisi her zaman tartışma konusu olmuştur; çünkü yazınsal metinlerde kişi adları gündelik dilden farklı olarak daha farklı anlam ve işlevler yüklenmekte, kişi adları gerçek anlamları (denotatif) dışında yan anlamlarıyla (konnotatif) da kullanılmaktadır.

Yazınsal metinlerde, özellikle de çocuk yazınında kişi adlarının önemli işlevleri vardır ve bu durum çevirmeni zor seçimlerle karşı karşıya bırakmaktadır. Çevrilebilirlik ile ilgili olarak Schleiermacher'ın şu sözleri anlamlıdır: "Bir dildeki hiçbir sözcüğün başka bir dilde tam karşılığı yoktur" (1813/1963, s. 42). Bu yaklaşım, kişi adlarının çevirisi konusuna uyarlandığında şu sorular akla gelir: Çevirmen kaynak metne sadakatini gösterip, isimleri koruyarak mı aktarmalı, yoksa erek kültüre göre isimleri çevirerek yeniden mi yaratmalıdır? Başka bir deyişle, kaynak metindeki kişi adları korunmalı mıdır, yoksa erek dile çevrilmeli midir?

Kişi adlarının çevirisi konusunda bir çeviri yaklaşımı geliştirmek, çevirmen için zor bir seçim olabilmektedir ve başvuracağı yöntem bazen ismin kendisinde saklıdır. Yazarın, karakterlerine verdiği isimleri hangi yöntemlerle seçtiğini çözümlemek, çevirmen için zorlu bir süreç olabilir. Bilindiği gibi kişi adları, dil-kültür ilişkisi bağlamında da değerlendirilmesi gereken konulardan birisidir. Her toplumun kendi değer yargılarına ve inançlarına göre bir ad verme geleneği vardır. Dolayısıyla özel isimleri inceleme konusu edinmiş ve dil çalışmalarında özel adları ele alan onomastik (adbilim), çevirmen için yol gösterici olabilir.

\section{ONOMASTIK}

“En eski dil çalışmalarından bu yana nasıl çeşitli dillerdeki sözcükler üzerinde durulmuş, bunların özellikle köken bilgisi yönünden açılanmasına girişilmişse, insanoğlunun merakı ve gerçeğe ulaşma isteğinden ötürü, özel adların aydınlatılmasına da çalışılmıştır" (Aksan, 1998-III, s. 91). Aksan'ın bu sözlerinden, isimlerin ve isim verme geleneğinin insanlar için her zaman ilgi çekici olduğu anlaşılmaktadır. Çünkü isimler, taşıyıcıları hakkında bazı bilgiler verir; isim sahibinin geçmişi, kökeni, mesleği, hizmetleri, dış görünüşü ve hatta ataları ve aile geçmişi hakkında ipucu verebilmektedir. İsimlerin anlam, köken bilgisine (etimoloji) ve yapısına duyulan ilgi, dilbilimin bir alanı olan 
onomastik (adbilim) alanının gelişmesine yol açmıştır (bkz. Blanar, 1981; Rospond, 1983; Althaus, 1980).

Yunanca kökenli bir kavram olan onomastik (Alm. Namenkunde, İng. Onomastics), geniş anlamda "(a)nlambilimle yakınlığı olan, ancak yöntem bakımından ondan ayrılan ve sözcük-kavram ilişkisine önem veren bilim dalı"dır. Dar anlamda ise, "(g)enellikle her dilde özel ad sayılan öğeler üzerinde duran ve özel adları köken bilgisi, tarihsel gelişme yönünden ve çeşitli dil ve kültür sorunları açısından inceleyen bilimdir" (Aksan, 1998-I, s. 32).

Onomastiğin inceleme alanına giren özel adlar bugüne kadar genel olarak "tek bir kişiyi, belli bir canlı ya da cansız varlığı, bir düşünce ya da belli bir yeri anlatan adlar" (Aksan, 1998-III, s. 92) olarak tanımlanmıştır. Türk Dil Kurumu'nun tanımına göre isim, “bir kelimeden, bir sözden, bir davranış veya olgudan anlaşılan şey, bunların hatırlattı̆̆ı düşünce veya nesne, mana, meal, fehva, deme, mazmun, medlul, valör" olarak tanımlanır.

Onomastik, gerçek isimlerin olduğu kadar, yazınsal isim verme geleneğini de kapsayan ve isimlerin oluş, ortaya çıkış ve tarihsel gelişimini ele alan, dilbilimin (özellikle de sözcük biliminin) bir araştırma alanıdır (Reallexikon, 2007, s. 745; Althaus, Henne \& Wiegand, 1980, s. 187). Onomastik bazı alt alanlara ayrılmaktadır: Kişi isimleri (antroponimler), yer isimleri (toponimler), nehir, ırmak ve göl isimleri (hidronimler), ülke, coğrafi bölge, sokak ve yerleşim birimi isimleri (oronimler). Kişi ve yer isimleri onomastik alanının ağırlıklı çalışma alanını oluşturmaktadır (Seibicke, 1982/2008, s. 4). Ayrıca hayvan isimleri (zoonimler), bitki isimleri (fitonimler ), eşya, bina, gezegen, kurum ve kuruluş, film, olay isimleri de onomastik biliminin araştırma alanına girmektedir (Heuser \& Schmuck, 2018; Lietz, 1992).

\section{YAZINSAL ONOMASTIK VE ONOMASTIK BİRIMLER OLARAK ÖZEL İSIMLER}

Kişi adları her ülkenin dünya görüşünü, gelenek göreneklerini, inanç sistemini, kısacası kültürünü yansıttığı için, her kültürde farklılık göstermektedir. Dolayısıyla farklı kültürlere ait yazınsal metinlerde yer alan kişi adları da kültüre özgüdür. Onomastiğin önemli bir bölümünü oluşturan yazınsal onomastik bu bağlamda önem taşımaktadır. Yazınsal Onomastiğin araştırma alanı yazınsal isimler ve yazınsal metinlerde isim verme geleneği ile yazınsal isimlerin eserlerdeki işlev ve etkileridir (Reallexikon, 2007, s. 745). İsimlerin hayatımızdaki anlamları dışında, yazınsal eserlerde yer alan kişi ve yer adları yazın için önem taşıyan yaratıcı bir unsurdur. Eserlerde yer alan karakter ve yerlere sanatsal isim verme sürecine ilgi giderek artmış ve böylece yazınsal onomastik alanı gelişmiştir (Sobanski, 2000, s. 35).

Zaman zaman yazarlar, gerçekte var olmayan sadece eserlerine özgü isimler yaratırlar, dolayısıyla burada yazarın yaratıcılığı söz konusudur. Yazarın isim verme veya yaratma süreci gelişigüzel bir eylem değil, deneyerek, değiştirerek, uygun bir isim bulana kadar devam eden, özenli bir arayışın sonucudur (Debus, 2002, s. 13-40). Bu yazınsal antroponimler, eserlerde en çok kullanılan onomastik birimlerdir (ad, soyad, lakap, mahlas gibi kişi adları). Bu birimler yazarın yazınsal amaçlarını vurgulamaya hizmet eder. Yazarlar, isimlerle eserlerindeki karakterlerin iç dünyasını betimlerken, karakterlerin özelliklerini ve (ulusal) özgünlüklerini de gösterirler. Yazınsal onomastik, yazarların isim verme sürecini ve kişi, yer ve eşya isimleri verirken hangi yol ve yöntemlere başvurduklarını araştırırken, aynı zamanda bu isimlerin etkisini, okur - yazar - eser etkileşimini de irdeler (Sobanski, 2000, s. 
24). Dolayısıyla yazınsal onomastik, dilbilim ve edebiyat bilim arasında bir köprü oluşturmaktadır.

Yazınsal metinlerde yer alan kişi adlarına olan ilgi çok eskilere dayansa da, bu alana önemli katkı sağlayan isimlerden biri Birus'dur (1978). Poetische Namensgebung adlı çalışmasıyla yazınsal onomastik ile dilbilim ve edebiyat bilimini birbirine yakınlaştırmıştır. Birus, eserinde yazınsal isimlerin sınıflandırmasını yapmışır. Debus ise 2002 yılında yayımladığı Namen in literarischen Werken adlı çalışmasında yazınsal isimlerle ilgili araştırma yöntemlerini ele almış, ayrıca yazınsal isimlerin sınıflandırması ve işlevi ile ilgili kapsamlı bir araştırma yapmıştır. Çalışmasında iki önemli nokta üzerinde durmuştur: Yazarların özel isim seçimleri ve bu isimlerin çevirisi. Yazınsal onomastik, yazınsal metinlerde yer alan tüm isimlerin yazınsal isim olduğunu varsaymakta ve bu isimlerin özel anlam ve işlevlerinin olduğunu kabul etmektedir. Yazınsal isim olgusunu etkileyen üç faktör vardır: Yazar, eser ve okur. En önemli faktör yazardır; çünkü isimlerin yaratıcısı ya da onları seçen kişidir, ancak yazarın isim seçimindeki gerekçelerini ortaya çıarmak çoğunlukla mümkün olmamaktadır. İsim seçme ve isim yaratma konusunda her yazarın farklı yaklaşımı ve motivasyonu vardır, ancak isim seçiminde hangi unsurların rol oynadığını sadece yazar bilir (bkz. Hanno Weber, 1997; Debus, 1998; Sobanski, 2000).

İsimlerin hangi amaçla seçildiğini bulmanın bir başka yolu da eserin kendisidir. Yazınsal metinde isimle ilgili göndermelerin olması, ismin meta olarak kullanılması, isim seçimine açıklık getirebilir. Yazınsal onomastik incelemelerinde, metnin isim seçimi ile ilgili doğrudan ya da dolaylı olarak bilgiler içerdiği gözlemlenmektedir (bkz. Krüger, 2006, s. 50).

İsim seçiminde bir diğer önemli etken de okurdur. Okur, isimlere anlam yükler ve yüklenen bu anlamlar zaman içerisinde değişkenlik gösterebilir, çünkü eserin yazıldığı zaman ve okurun eseri okuduğu zaman arasında geçen süre, isimlere yüklenen anlamları da değiştirecektir. Çeviri eserlerde ise daha büyük farklılıklar ortaya çıkar, çünkü eserin yazılmasıyla çevirisinin erek kitleyle buluşması daha da uzun bir süreçtir.

\section{YAZINSAL İSIMMLERIN SINIFLANDIRILMASI}

İsim verme sürecinde yazarlar farklı yollara başvurur. Yazarlar seçtikleri isimle karakterin geçmişini, kökenini, toplumsal sınıfını veya başka bir özelliğini aktarmaya çalışır. Yazınsal onomastik, yazınsal metinlerde yer alan isimlerin sınıflandırması ve işlevleriyle ilgilenir. Onomastik alanında çalışan kuramcılar kişi adlarıyla ilgili farklı sınıflandırmalar yapmıştır. Hendrik Birus'un (1987) kişi adlarının sınıflandırılması, Dieter Lamping'in (1983) ve Friedhelm Debus'un (2002) yazınsal isimlerin işlevlerine ilişkin çalışmaları alana önemli katkı sağlamıştır (bkz. Birus, 1978; 1979; 1987; Lamping, 1983; Debus, 2002; ayrıca bkz. Bödeker \& Freese, 1987; Bödeker \& Wetzel-Sahm, 1989; Stiegler, 1994; Seibicke, 1982/2008; Thies, 1978; Sobanski, 2000).

\section{HENDRIKK BIIRUS'A GÖRE YAZINSAL İSIMLERINN SINIFLANDIRMASI}

Alman onomastik çalışmalarında Birus'un $(1978 ; 1987)$ sınıflandırması birçok çalışma için kuramsal altyapıyı oluşturmuştur. Birus (1987) yazınsal isimleri dört gruba ayırmıştır.

\section{Sınıflandıran İsimler}

Birus dini inanca, ülkeye, topluma veya edebiyata özgü isim verme geleneğine bağlı olarak belli bir ismin taşıyıcılarını sınıflandıran (Birus, 1987, s. 45) isimleri bu gruba 
yerleştirmektedir. Mesela Maria ismi bize söz konusu karakterin cinsiyetini ifade etmekte, metindeki bağlamdan bu karakterin genç/yaşlı olabileceği, yaşadığı toplum, dini inancı vb. konusunda çıkarım yapılabilmektedir. Bu sebeple içinde yaşanılan kültürün isim verme geleneği, değerler, toplumsal sınıf, güncel akımlar isim verme sürecinin bir parçasıdır. Dolayısıyla yaşanılan ülke/coğrafya, uyruk, kültürel aidiyet, toplumsal unsurlar, zaman/dönem faktörü, dinî unsurlar isim verme sürecini etkileyen faktörlerdir (Birus, 1987, s. 45).

\section{Eser Dışında Kişi ve Karakterlere Gönderme Yapan İsimler}

Birus somutlaştıran isimlerin edebi eser dışında aynı ismi taşıyan bir kişiliğe gönderme yaparak anlam kazandığını ifade eder (Birus, 1987, s. 45; Lamping, 1983, s. 46).

\section{Tanımlayıcı İsimler}

Birus'a göre tanımlayıcı isimler isim sahibinin somut ve soyut özelliklerine, tutku ve alışkanlıklarına, mesleklerine, özel ilgi ve meraklarına, kökenlerine işaret ederek eserde yer alan kişileri adlandırmakla kalmaz, ayn zamanda isim sahibini daha yakından tanımlar (Gutschmidt, 1985, s. 141; Kalverkämper, 1978, s. 72). Tanımlayıcı isimler, taşıyıcılarını fiziksel veya psikolojik özelliklerine, alışkanlık ve tutkularına, mesleklerine, belli aktivite ve nesnelere karşı duydukları özel ilgilerine vb. işaret ederek (Uyuyan Güzel) sınıflandırabilirler. Tanımlayıcı isimler, çeviribilimde üzerinde durulması gereken en önemli isim grubuna girer (Birus, 1987, s. 45). Bu isimler çocuklara en çok hitap eden isim türüdür ve yazınsal eserlerde en çok yer alan isimlerdir (Birus, 1987, s. 47).

\section{Ses Sembolik İsimler}

Birus'a göre ses sembolik isimler, sesleriyle çağrışım yapan isimlerdir. Anlamlarını ikonik özelliklerinden alan (onomapoetik, sinestetik), sesleri çağrıştıran (Peter Pan: KlingKlang) yazınsal isimlerdir (Birus, 1978, s. 45). Birus bu isimlerin tek bir dile özgü olmadığını ve isim taşıyıcının öne çıan bir özelliğine gönderme yaptığını belirtir. Ses sembolik isimler görme-işitme gibi duyulara hitap eder: Bu isimlerde renkler duyulur, harfler hissedilir, sesler görülebilir. Dolayısıyla okurda seslerle belli imgeler canlandırılır ve isim sahibinin özellikleri ile ilgili çağrışımlar yapar. Birus bu isimlerin kesin çizgilerle tanımlanamayacak bir isim türü olduğuna dikkat çeker (Birus, 1987, s. 45).

\section{YAZINSAL İSIMLERIN IŞSEVLERI - FRIEDHELM DEBUS'UN SINIFLANDIRMASI}

Yazınsal eserlerde yer alan kişi adları, eserin temel yapı taşıdır ve önemli işlevlere sahiptir. Birus'un sınıflandırmasına benzer bir şekilde Debus (2002) da yazınsal isimlerin işlevleri üzerinde çalışmıştır. Debus'un çalışmaları, Dieter Lamping'in çalışmalarına dayanmaktadır (Lamping, 1983). Lamping yedi işlevden bahseder: Özdeşleşme, illüzyon yaratma, karakter özellikleri yükleme, vurgulama, anonimleştirme, perspektif yaratma, estetik değer yükleme, mitleştirme (Lamping, 1983, s. 7-8). Debus, Lamping'in bu işlevlerini genişletir ve eklemeler yapar.

\section{Özdeşleşme}

Debus'a göre yazınsal isimlerin en önemli işlevi, eser kahramanı veya karakterleriyle özdeşleşmesidir. İsim sahibi, yazar tarafından belli bir isimle tanımlanır ve belirlenen kişiliği taşır (Goethe-Faust: Thomas Mann-Dr. Faustus). Okur, karakteri ismiyle tanır. Bazen bir 
karakterin ismi metin dışında da yer alır veya başka bir metne gönderme yapabilir (Debus, 2002, s. 74).

\section{Kurgu / İllüzyon Yaratma}

$\mathrm{Bu}$ işlev sadece yazınsal isimlere özgüdür. Bu işlev ile, eser dışında da bilinen kişi veya kişiliklerin isimleri kurguya dahil edilip bir illüzyon yaratılır (Dürrenmatt-Fizikçiler: Einstein, Newton). İsimlerin gerçek taşıyıcıları kurgunun içinde yer alıp yazınsal isimlerin taşıyıcısı olan kurgusal karakterlerle, kurgusal gerçeklikte karşılaşır ve o gerçekliğin yaratıcısı olurlar. Dolayısıyla metnin illüzyon yaratması konusunda katkıda bulunur veya kurgusunun bir parçası olurlar (Lamping, 1983, s. 38; Debus 2002, s. 76).

\section{Kişilik Özellikleri Yükleme}

$\mathrm{Bu}$ işlev isim taşıyıcısını daha yakından tanımlar. Sınıflandırmada yer alan isimler yazar tarafından seçilip, karakterlere belli kişilikler yüklenir (Heidi: Adelheid-Asalet) (Debus, 2002, s. 77).

\section{Vurgulama - Anonimleştirme}

Bu iki özellik birbirine karşıt işlevlere sahiptir. Vurgulama işlevi, sanatsal/yazınsal yöntemlerle (ses, kelime oyunu vb.) bütün dikkati ismin kendisine çeker. Bunu yaparken isimle ilgili ideolojik, dini, toplumsal, psikolojik ve etimolojik vurgular da yapar ve yazar, ismi böylece ön plana çıarır. Anonimleştirmede ise isim daha gizemli-doğaüstü özelliklerle bağdaştırılır veya isimlerle ilgili tabular vurgulanır. (Örneğin bir isimle bağdaştırılan uğursuzluk, şanssizlık vb., Kara Kedi).

\section{Mitleştirme}

İsimlerin gizemli-sihirli güçlere sahip olduğunu vurgular ve isim taşıyıcısının bu özelliklere sahip olduğuna işaret eder. Yazınsal isimlerin en önemli işlevlerinden kabul edilir (Debus, 2002, s. 81).

\section{Estetik Değer Kazandırma}

Yazın eserini oluşturan en önemli işlevlerden biridir. Lamping bu işlevle, güçlü ifadeye sahip isimler yaratıldığından bahseder. Dolayısıyla okurda güçlü bir izlenim yaratılır. Bu isimler yazınsal esere estetik değer kazandırır ve eserle bütünleşir (Lamping, 1983, s. 103). Debus'a göre yazınsal isimler, büyük isim hazinesini (großer Namenwortschatz) oluşturan en önemli unsurlardır. Kurgusal isimlerin işlevleri ancak gerçek dünyayla olan etkileşimde anlaşlır. Bu yüzden gerçek ve kurgusal dünya iç içe geçmiş ve birbirine bağlıdır (Debus, 2002, s. 84).

\section{Kişi Adlarının Çevrilebilirliği}

Yazınsal onomastik, edebiyat bilim ve adbilim arasında bir köprü oluştururken, yazın çevirisi ise edebiyat bilim ve adbilim alanlarına çeviribilimi de dahil etmektedir. Çeviri sürecinde bu üç alanın etkileşim halinde olması, disiplinlerarası çalışmaların önemini ortaya koyar. Bu bağlamda Lamping (1983), Lietz (1992) ve Debus (1998) çeviri ile onomastik alanında önemli çalışmalar yapmışlardır. Özellikle Lietz (1992), çalışmasıyla adbilim ile çeviribilim alanlarının birlikte çalışması gerektiğini vurgulamış, kaynak metindeki kişi adlarının erek dile çevirisinde karşılaşılan sorunları ele almıştır. Çeviride karşılaşılan bu sorunları aşmak için, adbilimin geliştirdiği yaklaşımlarla birlikte çeviribilim stratejileri de dikkate alınmalıdır.

SEFAD, 2021; (45): 101-122 
Çeviribilimde bu bağlamda iki farklı çeviri yaklaşımı görülür; bunlar yerlileştirme ve yabancılaştırma yaklaşımlarıdır. Alman felsefecisi Friedrich Schleiermacher, çevirinin orijinal metne mi, yoksa orijinal metnin çeviriye mi yaklaşması gerektiği sorusunu, "ya çevirmen yazarı olduğunca rahat bırakır ve okuru ona doğru yaklaştırır; ya da okuru rahat bırakır ve yazarı ona doğru yaklaştırır" (1813/1963, s. 47, aktaran: Kurultay, 1985, s.198) şeklinde cevaplandırır. Yazarın okura yaklaştığı durumlarda, kaynak metnin yabancı unsurları ortadan kaldırarak yerlileştirme (Einbürgerung) stratejisinin benimsenmesi söz konusudur. Okur, yazara yaklaştırıldığında ise yabancılaştırma (Verfremdung) stratejisinden bahsedilir ve metindeki yabancı unsurlar erek metinde değiştirilmeden birakilır.

Çeviribilim araştırmacısı Lawrence Venuti yerlileştirme/yabancılaştırma (domestication/foreignization) kavramlarını Schleiermacher'ın çeviri konusundaki düşünceleri doğrultusunda yeniden ele almıştır. Venuti, yerlileştirme stratejisini kaynak metnin yabancılığının en aza indirgenmesi şeklinde tanımlar ve böylece çeviri metnin erek dil okurları tarafından kolaylıkla kabul gördügünü ileri sürer. Bu stratejide kaynak metnin kültürel ve dilsel farklılıkları azaltılır, yazar okura yaklaştırılır. Çevirmenin yerlileştirme stratejisini benimsemesinin çeşitli sebepleri olabilir. Burada erek dizgenin sosyo-kültürel veya siyasi kısıtları söz konusu olabilir (Venuti, 1998, s.240-241). Bu strateji doğrultusunda çeviri sürecinde farklı görünen kültürel unsurları çevirirken, kültürel unsurları çıkarma, atlama, değiştirme, ekleme, uyarlama (adaptasyon), kültürel eşdeğerini bulma gibi daha serbest çeviri stratejilerine başvurabilir. Yerlileştirme stratejisi erek kültür dizgesinin amaç ve değerlerinin sürdürülmesine hizmet eder. Çevirmen yerlileştirme stratejisini benimsediğinde kişi adları erek dile çevrilerek (metonomasi) aktarılabilir, bir isim transferiyle isim yeniden yaratılabilir (creation) veya başka bir kelime ile karşılanabilir (substitution). Bu yaklaşım, özellikle tanımlayıcı kişi adları için geçerlidir (Kalverkämper, 1996, s. 1021). Özel adların çeviri sorunlarına ilişkin araştırmaları olan Kalverkämper, kaynak dilde yer alan, anlamı olan ve çağrışım yapan bir özel adın anlamının erek dile çevrilmesi taraftarıdır (1996).

Öte yandan yabancılaştırma stratejisi okurun yazara götürüldüğü, erek okurun kaynak metindeki yabancı unsurlarla karşılaştığı süreçtir. Yabancılaştırma stratejisini benimseyen bir çevirmen kültürel unsurları çevirirken sözcüğü sözcügüne çevirme, tırnak işareti veya italik yazım ile farklılığı vurgulama, sözcüğü olduğu gibi aktarma (ödünçleme, öyküntü), dipnot, açıklama/açımlama gibi çeşitli çeviri stratejilerini benimser. Yabancılaştırma stratejisi, kaynak metnin dilsel ve kültürel özelliklerini koruyarak erek okuru yabancı kültüre götürür. Çevirmen yabancılaştırma yaklaşımında kişi adını kaynak dildeki haliyle koruyabilir ve kişi adları erek metinde yabancı kalır. Dolayısıyla bu çeviri yaklaşımıyla, kişi adının işlevlerinde kayıplar olacaktır. Tanımlayıcı isimlerin anlamı erek dile aktarılamayacak, bu isimler okura mesaj vermeyen, erek kültür dizgesine herhangi bir göndermede bulunmayan isimlere dönüşecektir. $\mathrm{Bu}$ isimlerin yaptı̆̆ çağrışım ve göndermeler kayba uğrarken, kaynak metnin yabancllı̆̆ı, yabancı kültürün öğeleri korunmuş olur (Krüger, 2004a, s. 145). Debus kişi adlarının çevrilmemesi gerektiğini, yazarın seçtiği ismi, ister anlamı olsun ister olmasın, dilsel bir gösterge gibi düşünmek gerektiğini ve değiştirmemek gerektiğini vurgular (Debus, 1998, s. 52).

Kişi adlarının çevirisinde çevirmenin hangi yaklaşımı benimseyeceğini belirleyen birtakım unsurlar vardır: 
- Kişi adlarının işlevleri,

- Kişi adının meta olarak kullanılması ve bu adla ilgili metin içinde göndermelerin yapilması,

- Metnin içerisinde yer alan kişi adlarının anlamı ile ilgili açıklamaların yapılması.

Çevirmen özel ismi yabancılaştırarak çevirdiğinde, erek dilde yabancı olan isim ile ilgili işlevleri çeviri süreci içerisinde aktarmalıdır. Yazarın metin içerisinde özel isimle ilgili verdiği işlevler, göndermeler ve çağrışımlar dolaylı olarak çevrilebilir. Dolayısıyla metin bir bütün olarak ele alınmalı, erek okur kitlesi için estetik ve iletişimsel işlevler dikkate alınmalıdır. Yazınsal metinlerde yer alan kişi adlarının yazar tarafından belirli amaçlarla seçildiği, bu adların okurlara belli bir takım çağrışımlar yapması istendiği düşünülürse, kişi adlarının hangi göndermeler ve kolektif çağrışımlar yaptığı, iletişimsel değeri çevirmen tarafından bilinmelidir. Dolayısıyla çevirmen kaynak ve erek okur kitlesinin isim verme geleneğini bilmelidir (Lietz, 1992, s. 297). Çevirmenin amacl, kişi adlarının çevrilebilirliklerini veya çevrilemezliklerini tartışmak olmamalı, daha çok kişi adlarına kaynak metinde yüklenen işlev ve anlamların, erek metinde de korunması hedeflenmelidir. Kişi adları çevrilmediği takdirde, erek metinde eşdeğer etkiye (Wirkungsäquivalenz) sahip olup olmayacağı belirsizdir. Kişi adlarının çevirisinde kullanılacak kişi adı erek metinde, kaynak metinde kullanılan kişi adına bir yandan göndermede bulunmalı, öte yandan da onun anlamını korumalıdır. Bunun için, kişi adı ilgili kaynak metinde yer alan tüm olumlu, olumsuz ve tarafsız çağrışımlar, imgeler ve duygular erek metine de aktarılmalıdır. Yazarın belli bir ismi seçmesinde bu etkenler etkilidir, çünkü okuyucu kitlesiyle ortak çağrışımlara sahiptir (kollektive namenpyhsiognomische Eindrücke) (Krüger, 2006, s. 52). Ancak çeviri eserlerde erek okuyucu kitlesinden ortak isim verme geleneği ve ortak çağrışımlar beklenmemelidir. Kaynak metinde geçen isimlerin erek okur tarafından bilinme ihtimali azdır. Bu nedenle kaynak metindeki kişi adları öncelikle çevirmen tarafından anlaşılmalıdır. İsimlerle okurda yaratılmak istenen işlev ve etki bilinmeli, yazarın belli bir ismi seçmesinin altında yatan nedenler anlaşılmalıdır. Bu etkinin erek okur kitlesinde aynı şekilde sağlanıp sağlanamaması veya ne oranda sağlandığı çevirmene bağlıdır. (Krüger, 2006, s. 52). Bu bağlamda kişi adları çevirisi değil, kişi adlarının çeviri sürecinde nasıl aktarılması gerektiği üzerinde durulmalıdır (Debus, 1997, s. 401). Dolayısıyla isimlerin çevrilebilir veya çevrilemez olmalarından çok, eserde taşıdığı anlam, iletişimsel ve estetik işlevi, diğer bir deyişle yazarın amacı, çeviri yoluyla ne ölçüde ve hangi çeviri stratejisiyle aktarılabileceği üzerinde durulmalıdır (Lietz, 1992, s. 129; Grassegger, 1985, s. 46). Özellikle yazarın isim seçiminde etkili olan yan anlamlar erek dile aktarımda önem taşımaktadır. Bu süreçte çevirmen, seçtiği çeviri stratejisiyle erek okur kitlesinde benzer çağrışım ve duygusal etkiler uyandırılıp uyandırılamayacağı sorusunu sormalıdır. Eğer kaynak metindeki isim değiştirilmeden aktarılırsa ve erek okur kitlesinde aynı çağrışımları yapmıyorsa, isim sadece bir referans olarak kalıp, anlamını kaybeder. Birus isimlerin özel statülerinden dolayı çevrilemez olduğunu öne sürer (Birus, 1987, s. 395). Her ne kadar öznel ve özgür bir seçim olsa da, yazarlar isim seçimlerini okur kitlesinin kolektif deneyimlerine dayandırırlar ve okur kitlesi için seçilen ismi anlamlandırmak bu deneyimlere bağlıdır (Krien, 1973). Ancak kolektif deneyimler her kültürde aynı olmadığından, çeviride erek kitleye aktarımda bu deneyim farklı olacağı için önemli çeviri zorlukları ortaya çıkacaktır.

Okuyucu kitlesinde yaratılan etki ve çağrışımın yanı sıra, metin bütünlüğü de yazarın isim seçiminde etkili olabilmektedir. Çevirmen, kişi adlarının erek dile aktarımında 
böylelikle seçilen ismin metin bütünlügüne gönderme yapıp yapmadığına, metinle bütünleşmeyi sağlayıp sağlamadığına dikkat etmelidir. Örneğin bir karakterin isminde yapacağ1 değişiklik başka bir ülkeyi temsil ediyorsa, ancak hikâye başka bir coğrafyada/ülkede gerçekleşiyorsa veya seçilen isim bambaşka, yazar tarafından amaçlanmayan yan anlamlara yol açıyorsa. Çeviri sürecinde çevirmenin başvurabileceği çeviri stratejileriyle ortaya çıkan isimler, erek kültürde ve dilde gerçek isim olarak algılanmalı ve erek kültürün isim geleneğine uygun olmalıdır. Çevirmenin uyarlayarak, yerine başka isim koyarak veya çevirerek yarattığı isim, erek dil ve kültür dizgesinde kabul edilebilir olmalıdır (Özbent, 2017, s.612-613).

\section{YAZINSAL İSIMLERIN ÇEVİRISİNDE YAKLAŞIMLAR}

Çeviri sadece bir dilden diğerine yapılan bir aktarım değil, aynı zamanda bir kaynak dizgesinde yer alan kültürel öğelerin erek kültür dizgesine taşınmasıdır. Özel isimler de kültürel öğe kapsamında ele alınır ve çeviride çevirmeni birtakım seçimlerle karşı karşıya bırakır. Çevirmen, bu öğelerin çevirisinde kaynak metin odaklı veya erek metin odaklı bir yaklaşım benimseyebilir. Bu bağlamda Gideon Toury'nin Betimleyici Çeviri Kuramı çevirmenin seçimleri konusunda yol gösterici olabilir. Toury çevirmen kararlarını belirleyen birtakım kısıtlayıcı normlardan bahseder. Çeviri yaklaşımını belirleyen bu normlar, çevirmen kararlarının ve çeviri stratejilerinin temelini oluşturur. Toury'nin yaklaşımına göre, öncül normlar çevirinin kaynak metne mi, yoksa erek metne mi daha yakın duracağını belirler. Kaynak metin odaklı yaklaşımı, "yeterli", erek metin odaklı yaklaşımı ise "kabul edilebilir" çeviri olarak tanımlar (Toury, 1995, s.53).

Adbilimin kişi adlarının çevrilebilirliklerine ilişkin sunduğu yaklaşımlar, çeviribilim çerçevesinde de önemli yer almaktadır. Adbilimin kişi adları ile ilgili sınıflandırmalarının, çeviribilim yaklaşımlarıyla birlikte değerlendirilmesi, çeviri sürecinde verilen kararlara 1şık tutabilir. Çeviribilim yaklaşımlarına bakıldığında kişi adlarının çevrilemeyeceği kanısını benimseyen yaklaşımların yanı sıra metni çocuk okur için daha kolay okunabilir ve daha tanıdık hâle getirmek için çeşitli stratejilere başvurarak isimlerin çevrilmesini savunan yaklaşımlar da var. Özel isimlerin çevirisinde benimsenecek yaklaşımın tek bir stratejiye dayandırılamayacağı söylenebilir. Özellikle de kişi adlarının nasıl çevrileceği veya çevrilip çevrilmemesi gerektiği hem yetişkin edebiyatı hem de çocuk edebiyatı kapsamında birçok kuramcı tarafından tartışılmıştır.

Çocuk ve gençlik edebiyatı araştırmacısı Göte Klingberg çocuk yazını çevirisinde kaynak metnin kültürel bağlamının erek kültür dizgesine uyarlanabileceğini savunur (kişi, yer isimleri). Ona göre kültürel farklılıklardan dolayı çocuk yazını çevirisinde başvurulan uyarlamalar (bağlam uyarlaması/context adaptation) kabul edilebilirdir (1986, s. 9-11, 65). Yazınsal isimlerin (tanımlayıcı isimler) erek dile çevrilmesi gerektiğini söyler, çünkü bu isimlerin yazar tarafından özellikle seçilmiş, göndermeler yapan isimler olduğunu vurgular. Diğer taraftan gerçek kişilere gönderme yapan kişi adları ve anlam taşımayan isimlerin korunarak aktarılmasından yanadır (1986, s.50-51).

Benzer bir sınıflandırmayı Theo Hermans da yapar. Hermans'ın yaklaşımına göre, özel isimler 2 grupta değerlendirilir: olağan (conventional) ve yüklü (loaded) isimler. Olağan özel isimler kendilerine ait bir anlam taşımazlar. Yüklü isimler ise çoğunlukla yazınsal metinlerde karşılaşılan ve metinde yer almasının özel bir nedeni olan isimlerdir (mesela takma isimler). Olağan isimlerin çevirisinde, uyarlama veya ödünçleme (transkripsiyon) 
yaklaşımları benimsenmektedir. Yüklü isimlerin çevirisinde ismin ne anlatmak istediği önem kazanmaktadır (1988, s.13).

Katharina Reiss, çocuk yazını çevirisinin uyarlamaları ve açıklamaları zorunlu kıldığını savunur. Önemli olan, erek metnin erek okur üzerinde kaynak metnin yarattığ benzer etkiler yapmasıdır (1982, s. 7).

Zohar Shavit'e göre çevirmen metinle ilgili kendisine olabildiğince serbestlik tanıyabilir. Metnin bütününde kısaltmalar veya eklemeler ve çıarmalar yapılabileceğini savunur. Shavit olay örgüsünün, karakterlerin ve dilin çocuğun kavrama yeteneğine uygun hale getirilmesinden bahseder (1986, s.112-128).

Christiane Nord'a göre özel isimlerin bilgilendirici olabileceğini ve kşi adlarından karakterlere dair ipuçları edinebileceğimizin altını çizmektedir. Nord'a göre kişi adları kültüre özgü öğelerdir ve çevirmenin görevi, kültürel öğelerin kaynak metinde sahip olduğu etkiyi hedef metne en uygun şekilde aktarmaktır (2003, s. 182-183).

Rita Oittinen, çocuk yazını çevirisinde öncelikle erek kitlenin çok önemli olduğunu ve çevirmenin çocukların neyi anlayabileceklerini bilmesi gerektiğinden bahseder. Çevirmen çeviriyi "çocuk okur"a göre yapmalıdır. Çocuk yazınında çevirmenin erek kitlesi olan 'çocuk'a sadık kalarak erek odaklı bir uyarlama stratejisi benimsemesi gerektiğini ifade eder (2000, s. 80-81).

Tiina Puurtinen çeviri çocuk yazınında "dilbilimsel kabuledilebilirlikten" bahseder ve erek okurun beklentilerine ve dilbilimsel uygunluğun dikkate alınması gerektiğini vurgular. Özellikle de fantastik öyküler ve makalelerde özel isimler, ünvanların, kültürel öğelerin çocuk okur için engel teşkil edebileceğini ifade eder. Bu unsurların çevirisinde erek kültür dizgesi dikkate alınması gerektiğini dile getirir (1995, s.20-23).

Turgay Kurultay, çocuk yazını çevirisinde kaynak metne sadık kalma zorunluluğunun bulunmadığından bahseder. Ona göre çocuk edebiyatından çevrilen bir metin, kaynak metne gerek duyulmaksızın iletişimsel işlevini yerine getirebilmelidir. Çevirmenin verdiği kararlar kaynak metnin değil "daha çok" erek kültür dizgesi doğrultusundadır (1994, s.119-201).

Neydim, çocuk yazını çevirisinde metne müdahalenin, uyarlama ve kısaltmaların mümkün olabileceğini söylemek tarihsel bir gerçeklik olduğu kadar bilimsel bir gereklilik olduğunu vurgular. Bu müdahaleler çevirmenin keyfine göre değil haklı gerekçeler çerçevesinde yapılması gerektiğini söyler (Neydim, 2006).

Bu yaklaşımlardan farklı olarak yabancı unsurların korunup çocuk okura kaynak kültürü tanıtmanın, ona yakınlaştırmanın da önemli olduğunu savunan yaklaşımlar da var. Bu bağlamda Selahattin Dilidüzgün'ün yaklaşımı önemlidir. Dilidüzgün çocuklar için anlaşılması çok güç olmadıkça özel isimlerin erek dile doğrudan aktarılması veya kaynak dildeki isme yakın bir isim erek dilde de mevcutsa uyarlama yapılmasını savunur. Uyarlamalarda ana figürlerin isimlerinin mümkün olduğunca değiştirilmemesin yerinde olacağını belirtir. Ancak isimlerin metinde belirli bir işlevi varsa, bu isimlerin taşıdıkları anlamın metin içerisindeki işlevlerinin erek dile aktarımı önem taşımaktadır (1993, s. 154160). Dilidüzgün, çocuk kitaplarının erek dil okuruna yeni bir bakış açısı kazandırması ölçütünü savunur ve bu bağlamda çocuk okurun yabancı unsurlarla karşılaşmasının önemli olduğunu vurgular (1993). 
Sonuç olarak kişi adlarının çevirisiyle ilgili çeviri yaklaşımlarında farklı görüşler belirtilse de, çocuk yazını çevirisinde kuramcılar erek metinde çocuklara uygun değişikliklerin yapılması gerektiğini savunuyorlar. Çevirmenin Toury'nin normlar bağlamında kısıtlandığını ve erek dil ve kültür dizgesine yakın "kabul edilebilir" çeviri yaklaşımını benimsedikleri çıkarımı yapılabilir. Yaklaşımlardan, çevirmen erek dizgeye yönelik değişiklikleri yapma zorunluluğuyla en çok kültürel değerleri (başlıklar, özel isimler, yer adları, deyimler, vb.) çevirirken karşı karşıya kaldığını görüyoruz. Yazarlar eserlerinde yer alan kişi adlarını, belli bir karakteri yansıtan ve bağlama da uygun tanımlayıcı/çağrışımsal isimlerden seçerler. Dolayısıyla yazarın seçtiği kişi adlarının erek kültür okuyucuları için de aynı anlamsal özelliklere sahip olması beklenir.

Kişi adlarının çevrilmesi konusunda çeviribilim yaklaşımlarının yanı sıra yazınsal onomastik, çevirmen için yol gösterici bir yaklaşım olabilir. Yazınsal onomastik, çeviribilim bağlamında dikkate alınması gereken bir alan olarak yazınsal metinlerde yer alan kişi adlarının çevirisi için bir ön aşama olarak değerlendirilmelidir.

\section{KURGUSAL KARAKTER İSIMLERINIIN ÇEVİIISINNE ÖRNEKLER}

Yukarıda üzerinde durulan onomastik çalışmaları, görüldüğü gibi dilbilim, edebiyat bilim, tarih ve kültür antropolojisi, felsefe, etnoloji, tarih gibi disiplinlerle de çok yakın ilişkidedir. Bu bağlamda çeviribilim ve onomastik bilimin disiplinlerarası çalışma gerekliliği ortaya çıkmaktadır. Bu çalışmada bu iki disiplinin birbirinden faydalanabileceği ve her iki alana katkı sağlayabileceği, bir çeviri örneğinde yansıtılacaktır. Onomastik alanı ışı̆̆ında, kişi adlarının taşıdığı anlam, işlev ve önemi, çeviribilim bağlamında tartışılacaktır. Bu amaçla Michael Ende'nin Wunschpunsch (1989) adlı çocuk kitabında yer alan kişi adlarının Almancadan Türkçeye çevirisi incelenecektir. Eser Leman Çalışkan'ın çevirisiyle Dilek Şurubu başlığıyla Almancadan dilimize kazandırılmıştır. Bu çalışmada eserin 2006 yılında Kabalcı Yayınevinde basılan çevirisi incelenecektir. Michael Ende'nin Wunschpunsch adlı eseri, çocuk yazını içerisinde fantastik özellikler içeren, biraz da masal niteliği taşıyan bir eser olarak değerlendirilebilir. Eserde gerçek dışı, fantastik, kurgusal karakter ve yer isimleri yer almaktadır. Kaynak metin incelenirken, çeviri yaklaşımlarının yanı sıra, özellikle de onomastik yaklaşım dikkate alınacaktır. Birus ve Debus'un sınıflandırmaları ışığında incelenecek olan çeviride, iki önemli unsur dikkate alınacaktır: Kurgusal karakter isimlerinin anlam ve işlevleri. Çevirmen, tanımlayıcı isimleri erek dile çevirirken, erek metin okurunun metni daha rahat okuması için erek kültürün repertuarına uygun isimler seçmiş, erek kültürün isim verme geleneğine bağlı kalarak yerlileştirme yaklaşımını benimsemiştir. Diğer taraftan, çevirmen anlam taşımayan, sınıflandırma ve tanımlayıcı özelliği bulunmayan isimleri erek metne taşımış ve yabancılaştırma yaklaşımını tercih etmiştir. Çevirmenin çeviri yaklaşımında isimlerin türlerine göre hareket ettiği gözlemlenmektedir. Dolayısıyla kaynak metinde anlam taşımayan kişi adları değişikliğe uğramadan, kaynak dildeki şekliyle korunarak doğrudan aktarılmış (yabancılaştırma, ödünçleme), ancak anlam taşıyan, tanımlayıcı isimler erek dile yerlileştirerek (uyarlama, kültürel eşdeğer) çevrilmiştir. Aşağıdaki örneklerde çocuk yazını çevirisinde çevirmeni yönlendiren normlar bağlamında ve adbilimin isim verme yaklaşımları 1şı̆̆ında, kurgusal isimlerin çevirisinde hangi yaklaşımlara başvurulduğu incelenecektir. 


\section{Sınıflandıran İsimlerde ve Gerçek Kişilere Gönderme Yapan İsimlerde Yaklaşımlar}

Michael Ende'nin fantastik eserinde yer alan kişi adlarının birçoğu, kurgusal ve gerçekle ilişkisi bulunmayan karakterlerden oluşmaktadır. Bu isimlerin çevirisinde yabancılaştırma yaklaşımına başvurulduğu görülmektedir. Kaynak metinde yer alan ve karakterlerin özelliklerine göndermede bulunmayan veya tanımlayıcı olmayan kişi adları erek dile değişikliğe uğratılmadan aktarıldığı, eserin ana karakterlerinden olan kedi Mauro örneğinde görülmektedir. Eserin önemli karakterlerinden şarkıcı kedi Mauro, kaynak metinde Maurizio Di Mauro (Ende, 1989, s. 27) ismiyle yer alırken, erek metinde Mauro Mauroğlu (Ende, 2006, s. 27) olarak aktarılmış, isim fazla değişikliğe uğratılmadan ödünçleme stratejisiyle aktarılmış. Yalnızca, Türkçede soy isimlerinde karşılaşılan -oğlu ekiyle (Mauroğlu) Türk isim verme geleneğine yakınlaştırılmıştır.

Kaynak metinde yer alan ve erek metne değiştirilmeden (ödünçleme), doğrudan aktarılan birçok örnek karşımıza çıkmaktadır: Kaynak metinde Nonne Bubu (Ende, 1989, s. 142), kişinin hikâye içerisindeki işlevini de ifade eden Nonne (rahibe) kelimesi de isimle birlikte belirtilmektedir, çünkü Bubu ismi belli bir anlam taşımamaktadır: Rahibe Bubu (Ende, 2006, s. 142). Fräulein Rosa (Ende, 1989, s. 91), Matmazel Rosa (Ende, 2006, s. 91) ve Ramona (Ende, 1989, s. 120) yine Ramona (Ende, 2006, s. 120) olarak birakılarak, bu isimlerde de aynı yönteme başvurulmuştur. Bu örnekler, isim sahibinin cinsiyeti dışında bilgi vermediğinden, tanımlayıcı isim olarak değerlendirilememektedir; dolayısıyla da erek okur için, hikâye içerisinde bir gönderme yapmadıklarından, erek metin okuru için içeriksel bir farklılık yaratmayacağı düşünülerek yabancılaştırılarak, ödünçleme stratejisiyle çevrilmiştir.

Ende'nin eserinde gerçek kişilere veya varlıklara gönderme yapan veya gerçek hayatta bulunan isimler de yer almaktadır. Bu isimlerde de yabancılaştırmaya başvurulmuştur. Bu isimler tanımlayıcı isim grubuna girmeseler de, gerçekte var olan veya bilinen kişilere/varlıklara gönderme yaptıkları için erek dile değiştirilmeden aktarılmışlardır. Dolayısıyla eser içerisindeki işlevlerine gönderme yapılmıştır. Kaynak metinde Schwager Asmodeus (Ende, 1989, s. 78) olarak yer alan isim erek dilde Enişte Asmodeus (Ende, 2006, s. 78), Schwester Lilith (Ende, 1989, s. 78), Kardeşim Lilith (Ende, 2006, s. 78), Onkel Zerberus (Ende, 1989, s. 82), Zerberus Amca (Ende, 2006, s. 82), Frau Medusa (Ende, 1989, s. 82), Eşi Medusa (Ende, 2006, s. 82), Klein Neron (Ende, 1989, s. 82), Küçük Neron (Ende, 2006, s. 82) olarak çevrilmiştir. Bu örneklerde kaynak ve erek metinde isimler hiçbir değişiklik yapılmadan yer almaktadır (transkripsiyon). Mitolojiden bilinen tanrı ve tanrıçalar, doğaüstü varlıklar ve onların isimleri, erek dilde de bu şekliyle bilindiği için (mesela Medusa) çevirmen bu isimleri çevirme gereği duymamıştır.

\section{Tanımlayıcı ve Ses Sembolik İsimlerde Yaklaşımlar}

Çevirmen, kaynak metinde yer alan tanımlayıcı isimleri ise farklı bir yaklaşımla çevirmeyi tercih etmiş̧tir. Hikâyenin içeriğine gönderme yapan ve erek okurun hikâyeyi anlamasına yardımcı olan, dolayısıyla bir işlevi bulunan isimleri erek dile çevirmiş ve yerlileştirme stratejisine başvurmuştur.

Eserin başkahramanı bir büyücüdür ve yazar, yarattığı bu karaktere kaynak metinde Geheimer Zauberrat Beelzebub Irrwitzer (Ende, 1989, s. 7) ismini vermiştir. Bu isim, büyücünün unvanını ve ismini içermektedir. Geheimer Rat, Almancada kullanılan, gizli konsey üyesi anlamına gelen bir unvandır. Ancak Büyücüler Konsey Üyesi veya Kurul 
Üyesi anlamına gelen Zauberrat, yazarın yarattığı bir unvandır. Kaynak metindeki unvan, Gizli Büyücüler Kurulu Üyesi şeklinde sözcüğü sözcügüne çevrilebilir, ancak çevirmen bu unvanı Büyücü Hazretleri İblis Şarlatan (Ende, 2006, s. 7) şeklinde çevirmeyi tercih etmiştir. Çevirmen kaynak dile değil, erek odaklı bir yaklaşımla, erek dil ve kültür dizgesine yönelik daha kabul edilebilir bir çeviri yapmıştır. Beelzebub Irrwitzer ise büyücünün gerçek adıdır ve iki isimden oluşmaktadır. Beezlebub, İbranice bir sözcük olup, Baal Zebub/Ba'al Zubab kökeninden gelmektedir. Anlamı Sineklerin Efendisi'dir ve İbrahimî dinlerde önemli bir şeytani figür olarak tasvir edilmiş bir tanrıdır. İsmin etimolojisine bakıldığında İblis'in uygun bir seçim olduğu söylenebilir. Yerlileştirme stratejisine başvurarak ismin/unvanın anlamına açıklık getirirken, (sözü edilen kişinin kötülük yapan bir karakter olduğunu vurguluyor) erek kültür dizgesine göndermede bulunmuş. Erek dilde (Türkçede) Beezlebub kelimesi bir anlam taşımıyor, ancak çevirmen kelimenin etimolojisinden yola çıkarak ismin ve de karakterin şeytani özellikler taşıdığını vurgulayan bir sözcük seçmiştir: İblis. Büyücünün ikinci ismi Irrwitzer kelimesi, Irrwitz, Almancada absürd, akla mantığa aykırı, anlamsız bir durum için kullanılan bir sözcüktür. Yazar, bu iki sözcüğü kullanarak bir isim uydurmuştur. Erek metinde ise çevirmen Almanca sözcügün anlamını vererek şarlatan karşılığını bulmuştur. İsim, büyücünün hikâye içerisindeki kişiliğini yansıtmakta, dolayısıyla da erek okur için ipuçları içermekte ve hikâyenin içeriğine gönderme yapmaktadır.

Ende'nin bu eserinin fantastik bir masal niteliği taşıması sebebiyle, yarattığı kurgusal karakterlerin isimlerinin bazılarının çevirisinde çevirmen, Türkçenin isim verme geleneğine yakın bir yaklaşım seçmiştir. Buna Maledictus Made (Ende, 1989, s. 14) ismi örnek gösterilebilir. Erek metinde Melun Kurtçuk (Ende, 2006, s. 14) ile karşılanmıştır. Latincede Male sözcüğü hasta, dictus ise söylemek, lanetlenmiş anlamına gelen bir sözcüktür. Made ise kurt, solucan anlamına gelir. İsim Melun Kurtçuk şeklinde sözcüğün kelime anlamı verilerek erek dile çevrilmiştir. Arapça bir sözcük olan melun, lanetlenmiş anlamına gelen ve erek dilde kullanılan bir sözcüktür. Melun Kurtçuk kurgusal bir isim olsa da erek dilin isim verme geleneğine yakınlaştırılmış, anlamsal karşılık da verildiği için, isim sahibinin karakterine gönderme yapılarak iletişimsel eşdeğerlik sağlanmıştır.

Kaynak metinde yer alan bir diğer isim Tyranna Vamperl (Ende, 1989, s. 40) de benzer bir yaklaşımla çevrilmiş, erek dile Zalime Vampirsoy (Ende, 2006, s. 40) şeklinde aktarılmıştır. Almancada Tyrann sözcüğü despot anlamına gelir, Vamperl kelimesi yerine kullanılan Vampir kelimesi de yazar tarafından değiştirilerek oluşturulan bir sözcüktür. Erek dilde Zalime Almanca Tyrann kelimesine karşılık gelir ve Vampirsoy ile de Türk isim verme geleneğine yakınlaştırılarak bir ek almıştır. İsim sahibinin hikâye içerisindeki kişiliği ve dolayısıyla karakterin rolü ve ismin işlevi hakkında bilgi veren benzer bir isimle, kültürel eşdeğer bir isimle karşılama yapılmıştır. Çevirmen böylece erek okurun dil ve kültür dizgesine yakın bir yaklaşım benimsemiştir.

Ende'nin eserinde ses sembolik isimlere örnek gösterilebilecek bir isim de Mioderich der Große (Büyük Mioderich) (Ende, 1989, s. 58) ismidir. Bu kurgusal bir isimdir ve kaynak dilde böyle bir isim bulunmamaktadır. Kedi Mauro, ataları hakkında bilgi verirken, onlardan birisinin adının Mioderich der Große olduğunu söyler. Kedilerin çıkardığı seslerden (Alm. miauw) yola çıkarak yazarın verdiği bu isim, Türkçede de aynı isim verme geleneği izlenerek (Tr. miyav) Büyük Miyavderik (Ende, 2006, s. 58) şeklinde çevrilmiştir. Bu örnekte de isim, erek okura isim sahibi hakkında bilgi vermektedir. 
Kaynak metinde Filmdiva Megära Mumie (Ende, 1989, s. 84) ismi, Türkçede Hollywood'daki Film yıldızı Mebure Mumya (Ende, 2006, s. 84) ile karşılanmıştır. Megära, Yunan Mitolojisindeki tanrıçalardan, Erinyelerden biridir. Türkçe metinde bu kelimenin "Mebure" ile karşılanmasının nedeni, fonetik benzerliğinden kaynaklanabileceği düşünülebilir. Mebure ismi, Mebrure ismine benzerliği ile dikkat çekmektedir. Mebrure, Arapça değerli, beğenilen anlamına gelmektedir. Dolayısıyla bu seçimle, anlamsal bir eşdeğerlilik sağlanmaya çalışıldığı söylenebilir, çünkü isim sahibi bir Hollywood film yıldızıdır.

Benzer bir yaklaşım Schwester Ghoulchen (Ende, 1989, s. 82) isminde de seçilmiştir. İsim erek metinde kız kardeş Gulyabaniak (Ende, 2006, s. 82) şeklinde, anlamsal karş1lı̆̆ verilerek aktarılmıştır. Almancadaki Ghul sözcüğü cin, şeytan anlamlarına gelen Dämon sözcüğüne karşıllık gelir. Hem Almanca Ghul kelimesi hem de yine aynı anlama gelen Türkçede yeralan gulyabani sözcüğü, Farsça Gul-i beyabani, gulyabani sözcüğü ile Türkçede isimleştirilerek kız kardeş Gulyabaniak şeklinde erek dile aktarılmıştır. Bu örnekte de erek dil ve kültür dizgesine yakın bir seçimle erek okura yaklaşan bir strateji uygulanmıştır.

Başka bir örnekte Opa Belial (Ende, 1989, s. 79) ismi yer almaktadır ve Belial sözcüğü ile İbranice sözcük Beli-ya'al (değersiz), Musevi ve Hıristiyan metinlerde şeytan ile bağdaştırılan bir kelimedir. Bu sözcük, kötü, değersiz şeyleri karakterize etmek için kullanılan İbranice bir kelimedir ve Türkçe metinde Şeytan ile karşılanmıştır (Bizim Büyükbaba Şeytan) (Ende, 2006, s. 79). Çevirmen tanımlayıcı isimleri Türk ad verme geleneğine yakınlaştırmış, anlamsal ve biçimsel olarak eşdeğer bir çeviri sağlamıştır. Erek dile çeviride anlam açıklanarak, iletişimsel eşdeğerlik dikkate alınarak yapılmış bir çeviri söz konusudur. Bu yaklaşımda dikkat çeken nokta, bu isimlerin hikâyenin içeriğine gönderme yapmaları ve karakterlerin eserdeki işlevleri ile ilgili olmalarından kaynaklanmaktadır. Bu gruptaki isimlerin hepsi kaynak metinde olumsuz çağrışım yapan isimlerdir ve erek metinde de aynı şekilde aktarılmışlar, dolayısıyla metne gönderme yapma işlevlerini anlamsal olarak da yerine getirmiş olmaktadırlar.

Kaynak metinde yer alan bir başka grup ismi ise çevirmen erek dilde bambaşka isimlerle karşılamıştır. Söz konusu eser fantastik yazın olduğundan, eserde fantastik unsurlar ve kişiler yer aldığ 1 için, kaynak metinde yer alan isimler kaynak dilde gerçekte var olmayan, kurgusal isimlerden oluşmaktadır. Yazar, hayal gücü ve yazınsal yetenekleriyle yeni sözcükler üretmiştir. İsmi başka bir isim ile karşılamıştır. Buna örnek olarak Büchernörgele (Ende, 1989, s. 193) gösterilebilir. Bu isim kurgusal, kaynak dilde var olmayan bir isimdir. Bücher (kitaplar) isminden ve nörgeln (dırdır, kusur bulma, eleştirme) fiilinden oluşturulmuştur. Eserde bir kitap eleştirmenine gönderme yapan bir isimdir. Bu isim erek dilde Akıldane (Ende, 2006, s. 193) şeklinde bambaşka bir isimle karşılanmış, anlamsal eşdeğerlik gözetilmiştir.

Liebes Dioxinchen (Ende, 1989, s. 17) ismi, yine yazarın uydurduğu bir isimdir. Dioxin kimyasal bir maddedir ve bu isimle metin içerisinde bir gönderme yapılmakta, çevreye zarar veren bir karakter kastedilmektedir. Türkçe metinde bu gönderme kaybolmaktadır, çünkü çevirmen ismi Sevgili dostum (Ende, 2006, s. 17) şeklinde çevirmiş ve kaynak metindeki ismi çevirmemiş, hitap şekliyle ifade etmiştir. Bu örneklerde, kaynak dildeki kişi adlarının yerlileştirme stratejisiyle erek dile çevrildiğini, bu yapılırken, bazen kaynak dildeki ifadenin yerine başka bir sözcükle ifade edildiğini (substitution), bazen de fonetik benzerlik gösteren kişi adlarının tercih edildiğini görüyoruz. Yerine geçme (substitution), bir dil öğesinin, ona 
denk olan, aynı anlamı veren başka bir öğeyle değiştirilmesidir. Dolayısıyla bu örneklerde yerlileştirme stratejisiyle yabancı isimlerin yerine erek dilde kullanılan adlar verildiği görülmektedir.

Bu örneklerde kaynak metinde yer alan bazı isimlerin, bileşik sözcüklerin, fantastik betimlemelerin karşılıkları erek kültür repertuarında bulunmamaktadır. Bu nedenle, çevirmenler bu isimleri aktarırken erek okuyucunun daha rahat okuması ve metni erek okuyucu için daha tanıdık hâle getirmek amacıyla kendileri bu karakterlere karşılık gelebilecek uygun isimler türettikleri görülmüştür. Erek metinde her iki çeviri yaklaşımının da kullanıldığı dikkat çekmektedir; bazı isimler uyarlanarak erek dile çevrilmiş, bazı isimlerin de kaynak metinde yer aldığı şekilde korunduğu, yabancılaştırarak çevrildiği görülmektedir. Dolayısıyla çocuk yazını çevirisinde kişi adlarının anlam ve işlevleri (onomastik değerleri) çeviri yaklaşımını da belirlediği söylenebilir. Erek kültür ve dil repertuarında var olan isimler yabancılaştırma yaklaşımı ile korunduğu, erek dil ve kültürde bilinmeyen isimlerin erek dil okurunun anlam ve mesajını çözebileceği isimlerle karşılandığı, yerlileştirilerek uyarlandığı gözlemlenmiştir.

\section{SONUÇ}

Bu çalışmada, günümüz çocuk yazını çevirisinde yer alan kişi adların erek dile nasıl aktarıldığı, hangi çeviri yöntemlerinin kullanıldığı bir eser örneğinde tartışılmıştır. Erek dilde kişi adları karşılık buluyor mu, hangi çeviri yöntemiyle nasıl çevriliyor soruları araştırılmıştır. Yapılan araştırma sonucunda görülmüştür ki, metnin erek dile çevirisinde kişi adlarının işlevleri çevirmen için ölçüt olmuştur. Çocuk yazını çevirisinde kişi adları erek dilde yerlileştirilirken veya içerdiği anlama göre uyarlanırken, hiç değiştirilmeyen, korunan ve böylece yabancılaştırılan isimler de bulunmaktadır. Bu şekilde yabancılaştırmanın nedeni, çocuklara kendi dünyalarından, çevresinden ve kültüründen de çıkarım yapabileceği ve her ne kadar çok daha farklı fantastik ve yabancı bir dünyanın olduğu ortamdan isimler yer alsa da, erek okurun kendi kültüründe ve dilinde aşina olabileceği isimler olduğu düşünülerek (mesela Medusa), bu isimlerin yabancı kalmasının uygun olduğunun düşünülmüş olmasıdır.

Çocuk yazını çevirisinde kişi adlarının en önemli görevi, kişileri ve yerleri tanımlamak, onlara bir kimlik kazandırmaktır. Bu nedenle özellikle karaktere yönelik ipuçları veren kişi adlarının erek dile çevrilmesi, çocukların karakteri daha kolay çözmesine ve daha kolay hatırlamasına yardımcı olur. Bunun yanı sıra, kaynak metinde kültürel vurgulama yok ise, kişi adlarının belirgin bir işlevi yoksa ve çağrışımsal yapıda değilse isimlerin yerlileştirildiği gözlemlenmiştir.

Çocuk yazını çevirisinde, kaynak metinde bulunan yabancı kişi adları, yaptığı çağrışımlara, göstergesine, anlamına erek dilde eşdeğeri olup olmadığına dikkat edilerek çocuklar için en doğru karar olacak bir yaklaşımın benimsenmesi gerekmektedir (bkz. Arı, 2018, s.223). Çocuklara yönelik kurgusal karakterlerin kurgusal adların eğer kaynak metinde bir anlamı varsa, bir çağrışım yapıyorsa, bir işlev yükleniyorsa, erek kültür okuyucusu için de bu işlevinin yerine getirmesi erek metinin anlaşlabilirliği kolaylaştıracaktır. Kişi isimlerinin yabancılaştırılarak, ödünçleme yoluyla erek dile aktarılması erek metnin anlaşılabilirliğini zorlaştıracaktır. Erek okur için kişi adlarını anlamlı hale gelmeyecek, erek dil ve kültür dizgesine göndermeler kaybolacaktır. 
Çeviri, kaynak kültür ile erek kültür arasında bir köprü vazifesi görmekte olup zaman zaman kaynak kültürü erek okuyucuya tanıtma görevini de üstlenmektedir. Bu işlevleri yerine getiren çevirmen, çeviri sürecinde birçok zorluk ile karşılaşır ve bu zorlukları aşmak için çeşitli çeviri stratejilerine başvurmaktadır. Bu zorluklardan biri de kültürel öğe kabul edilen kişi adlarının çevirisidir. Çevirmen kimi zaman metnin yabancı bir kültüre ait olduğunu ve okunan metnin çeviri metni olduğunu hissettirerek yabancilaştırıcı çeviri startejilerine başvurmayı, kimi zaman ise çocuk yazını çevirisinde yazınsal metni olabildiğince yerlileştirmeyi, dolayısıyla yabancı unsurları ortadan kaldırmayı tercih edebilmektedir. Amaç ise, çocuk okuyucuların metni okurken herhangi bir yabancılık veya zorluk yaşamamasıdır. Bu bakımdan kişi adlarının çevirisinde çevirmen, erek okuyucunun hikâyeyi anlaması için, isimlerin işlevlerini dikkate alarak çeviriye yaklaşmalıdır. Eserin anlaşılmasında işlevi olmayan isimleri çevirirken, gerçek hayattan alınan kişilerin isimlerini ve eserin içeriğine anlamsal açıdan katkı sağlamayan isimleri koruyarak aktarabilir. Eserin anlaşılmasında işlevi olan kişi adlarının ise erek kültürün isim verme geleneğine yakın isimler yaratılarak yerlileştirmesi anlamlıdır. Çevirmenin söz konusu kişi adlarını Toury'nin metinsel-dilsel normlar bağlamında Türkçe isimlerle değiştirerek erek dizgeye yakın durduğu söylenebilir. Böylelikle erek okur, hikâyedeki kişileri yaşadığı toplumunun ve ait olduğu kültürün bir parçası olarak görecek, kaynak metinde verilmeye çalışılan mesajları da kolayca benimseyecektir.

Çalışmamızda incelenen çeviride, çevirmenin kişi adlarını aktarırken farklı yollara başvurmuş olduğu açık bir şekilde örneklenmektedir. Örnekler çevirinin tek bir yönteme dayandırılamayacağını göstermistir. İncelenen metinde çevirmenin kişi adlarının işlev ve anlamlarını dikkate alarak, onomastik incelemelerini yapmış olduğunu, çeviri yaklaşımını bu doğrultuda gerçekleştirdiği söylenebilir. Bu çalışmada kişi adlarının Birus ve Debus'un sınıflandırmalarından yola çıkılarak, çeviri yaklaşımları ve çevirmen kararlarını yönlendirebileceği, dolayısıyla kişi adlarının çevirisinde başvurulabilecek bir yaklaşım olduğu tartışılmıştır.

Bu çalışmada çocuk yazınında kişi adlarının ve çevirilerinin incelenmesine yönelik araştırmalarında onomastik incelemelerin çeviribilim araştırmaları için yön verici olabileceği ve onomastik-çeviribilim alanlarının disiplinlerarası çalışmasının iki alana da katkı sağlayabileceği düşüncesinden yola çıkılmıştır.

Yazınsal metinlerde çeviri yaklaşımını belirleyecek en önemli unsur, kaynak metinde yer alan kişi adları ve onların işlevidir. Yazınsal onomastik alanının çıktıları bu bağlamda çeviribilim için önemli ipuçlarını verebilecek niteliktedir. Bu iki alanın birlikte çalışmasının önemi bu çalışmayla gösterilmeye çalışılmıştır. Ancak bu çalışmada değinilmeyen, fakat çeviri sorunu yaratabilecek birçok konu vardır. Bunlardan bazıları kişi adlarında çift anlamlılık, isimlerde kafiye, isimlerle yaratılan kelime oyunlarıdır. Kişi adlarının çevirisi ile ilgili çalışılabilecek daha çok konu olduğu açıkça görülmüş ve üzerinde çalışılması gereken bir alan olduğu düşünülerek bu çalışmayla alana bir katkı sağlanması amaçlanmıştır.

\section{SUMMARY}

In today's world characterised by globalisation, intensive cultural exchange, lightningfast communication, and foreign language acquisition, it is important to examine the contribution of onomastics (onomatology) to translation in the discussion of translation approaches. There has been an ongoing discussion especially on problems arising in the 
transfer of proper nouns in translated children's literature and approaches to their translation. As discussions are centred around source-oriented and target-oriented translation approaches, this study explores how literary onomastics can guide the translator. In contrast to target-oriented or source-oriented approaches, an onomastic approach can give important clues to the translator of children's literature about where the literary work leads the translator and the importance of the interaction between the author, literary work, proper nouns, and readers. This study focuses on the translation of personal names in translated children's literature and examines the meaning and function of personal names in children's literature within the framework of onomastics.

The tradition of naming dates back to ancient times and is maintained in different forms (religious, social, etc.) in each culture. Names vary in each country as they vary according to the geography and culture in which they exist. The tradition of naming is also reflected in the literature and literary works of countries. The translation of personal names has a special place in literary translation. The translation of personal names has always been a topic of discussion in literary translation because personal names carry different meanings and functions in literary texts than in everyday language and are used to refer to their connotative (implied) meaning as well as their denotative (literal) meaning.

Personal names have critical functions in literary texts, especially in children's literature. This presents the translator with difficult choices. Concerning the issue of translatability, Schleiermacher's following comment makes sense: "No word in one language has an exact equivalent in another." (1813/1963, p. 42). If this remark is considered in relation to the translation of personal names in literary texts, the following questions arise: Should the translator be faithful to the source text and preserve personal names in the target text exactly as there are in the source text? Or should the translator recreate personal names according to the target culture? In other words, should personal names in the source text be preserved or translated into the target language?

Developing a translation approach to translating personal names may be challenging for the translator. The translator's method or strategy to translate personal names may sometimes be specific to each name. Analysing how the author chooses character names is a challenging process for the translator. Personal names should also be evaluated in the context of the relationship between language and culture. Each society has a tradition of naming according to its own value judgements and beliefs. Therefore, onomastics that studies proper names can be a guide for the translator.

Personal names reflect each country's culture including worldviews, customs, and beliefs; thus, they differ in each culture. Therefore, personal names in literary texts are also specific to the culture in which these texts are produced. Literary onomastics, which form an important part of onomastics, are of key importance here. The research area of literary onomastics covers literary names, the tradition of naming in literary texts, and the functions and effects of names in literary works (Reallexikon, 2007, p. 745). Apart from the meaning of names in our lives, personal and place names in literary works are creative components that hold an important place in literature. There has been a growing interest in the process of giving artistic names to characters and places in literary works, thereby giving rise to the emergence of literary onomastics (Sobanski, 2000, p. 35). 
Authors sometimes create names that are specific only to their work and do not actually exist. This is about the author's creativity. The author's process of naming or creating is not an accidental act but the outcome of a painstaking search that continues until the author finds a suitable name by trial and error (Debus, 2002, p. 13-40). These literary anthroponyms are the most commonly used onomastic units (person names such as first names, last names, nicknames, and pseudonyms) in literary works. These units serve to emphasise the author's literary goals. Authors describe the inner world of their characters through names and explicate the characteristics and (national) originality of the characters. Literary onomastics focuses on how authors name their characters, explores the strategies and methods that authors use to name people, places, and objects, and examines the impact of these names and the interaction between the author, text, and readers (Sobanski, 2000, p. 24). Therefore, literary onomastics serves as a bridge between linguistics and literature.

It was clearly observed that the translator resorted to different ways when rendering personal names in the translation examined in this study. Examples showed that translation cannot be based on a single method. It can be said that the translator conducted an onomastic examination and accordingly chose the translation approach by taking into account the functions and meanings of personal names. Based on the classifications of personal names proposed by Birus and Debus, it seems that onomastics can guide translation approaches and translator decisions; thus, it is an approach that can be used in the translation of personal names.

In this context, onomastic studies can be a guide for translation studies research on the translation of proper names in children's literature and the interdisciplinary collaboration between translation studies and onomastics can contribute to both fields.

Personal names and their function in the source text are the key elements that determine the translation approach in literary texts. Thus, the outputs of literary onomastics can give important clues for translation. This study tries to show the importance of collaboration between translation studies and onomastics. However, many issues that were not addressed in this study may cause translation problems. Some of these are double meanings, rhymes, and wordplays created using personal names. All in all, it is hoped that this study provides valuable insights into the role of literary onomastics in the translation of personal names in literary works. It is clear that there are more topics to study in relation to the translation of personal names.

Makale Bilgileri

\begin{tabular}{ll}
\hline Etik Kurul Kararı: & Etik Kurul Kararından muaftır. \\
Katılımcı Rızası: & Katılımcı Yok \\
Mali Destek: & Çalışma için herhangi bir kurum ve projeden mali destek alınmamıştır. \\
Çıkar Çatışması: & Çalışmada kişiler ve kurumlar arası çıkar çatışması bulunmamaktadır. \\
Telif Hakları: & Telif hakkına sebep olacak bir materyal kullanılmamıştır. \\
Article Information & \\
\hline Ethics Committee Approval: & Exempt from the Ethics Committee Decision. \\
$\begin{array}{l}\text { Informed Consent: } \\
\text { Financial Support: }\end{array}$ & No participant \\
Conflict of Interest: & No financial support from any institution or project. \\
Copyrights: & No conflict of interest. \\
\hline
\end{tabular}

SEFAD, 2021; (45): 101-122 


\section{KAYNAKÇA}

Aksan, D. (1998). Her yönüyle dil: Ana çizgileriyle dilbilim. Ankara: Türk Dil Kurumu Yayınları.

Althaus, H. P. , Henne, H. \& Wiegand, H. (Ed.). (1980). Lexikon der Germanistischen Linguistik. Tübingen: Niemeyer Verlag, 187-198.

Arı, S. (2018). Çeviri çocuk edebiyatı örneğinde kültürel sembollerin eşdeğerlilik ilişkisi. Uluslararası Bilimsel Araştırmalar Dergisi (IBAD), 217-223.

Birus, H. (1978). Poetische Namensgebung: Zur Bedeutung der Namen in Lessings Nathan der Weise. Göttingen: Vandenheock \& Ruprecht.

Birus, H. (1987). Vorschlag zu einer Typologie literarischer Namen. Zeitschrift für Literaturwissenschaft und Linguistik 67, 38-51.

Bödeker, B. \& Freese, K. (1987). Die Übersetzung von Realienbezeichnungen bei literarischen Texten: Eine Prototypologie. TextconText 2/3. Heidelberg: Julius Groos Verlag, 137-165.

Bödeker, B. \& Wetzel-Sahm, B. (1989). Eigennamen und sprechende Namen. FRANK, 235242.

Debus, F. (1997). Eigennamen in der literarischen Übersetzung. Grammatica Ianua Artium. Heidelberg: Universitätsverlag C. Winter, $393-405$.

Debus, F. (1998). Dichter über Namen und ihr Umgang mit ihnen. Onomastica Slavogermanica XXIII, 33-59.

Debus, F. (2002). Namen in literarischen Werken. (Er-)Findung - Form - Funktion. Akademie der Wissenschaften und der Literatur Mainz, Abhandlungen der Geistes- und Sozialwissenschaftlichen Klasse, Jg. 2002, Nr. 2, Stuttgart: Steiner.

Dilidüzgün, S. (2005). Çă̆daş çocuk yazını: Yazın eğitimine atılan ilk adım. İstanbul: Morpa Kültür Yayınları.

Eichler, E. , Hilty, G., Löffler, H., Steger, H., Zgusta, L. (Haz.). Namenforschung. Ein internationales Handbuch zur Onomastik. 2. Teilband içinde (1018-1025). Berlin, New York: Walter de Gruyter.

Ende, M. (1989/2015). Der satanarchäolügenialkkohöllische Wunschpunsch. Stuttgart: Thienemann-Esslinger.

Ende, M. (2006). Dilek Şurubu. (Leman Çalışkan, Çev.). İstanbul: Kabalcı Yayınevi.

Grassegger, H. (1985). Sprachspiel und Übersetzung - eine Studie anhand der Comic-Serie "Asterix“. Tübingen: Stauffenberg Verlag.

Gutschmidt, K. (1985). Namenarten und Namenklassen in der schönen Literatur. Linguistische Studien A 129/I, 138-145.

Hanno Weber, S. (1997). Namengebungsmotivationen zeitgenössischer Hamburger Autoren. Eine empirische Untersuchung zur Literarischen Onomastik. Frankfurt a. M., Berlin, Bern, New York: Lang. (=Europäische Hochschulschriften: Reihe 1, Deutsche Sprache und Literatur Bd. 1598).

Hermans, T. (1988). On Translating Proper Names, with reference to De Witte and Max Havelaar. London/Atlantic Highlands: The Athlone Press 
Heuser, R. \& Schmuck, M. (2018). Sonstige Namenarten. Stiefkinder der Onomastik. Berlin: Walter de Gruyter.

Kalverkämper, H. (1978). Textlinguistik der Eigennamen. Stuttgart: BNF 14.

Kalverkämper, H. (1996). Namen im Sprachaustausch: Namenübersetzung.

Klingberg, G. (1986). Children's fiction in the hands of the translators. Lund, Malmö: CWK Gleerup.

Krien, R. (1973). Namenphysiognomik. Untersuchungen zur sprachlichen Expressivität am Beispiel von Personennamen, Appellativen und Phonemen des Deutschen. Tübingen: Max Niemeyer.

Krüger, D. (2004). Eigennamen in der literarischen Übersetzung. Dargestellt am Beispiel von Übersetzungen von J. K. Rowlings 'Harry Potter'. Namenkundliche Informationen 85/86 içinde (141-163). Leipzig: Leipziger Universitätsverlag.

Krüger, D. (2005a). Literarische Onomastik in Deutschland, mit einem Beispiel aus der Übersetzungspraxis. Onoma - Journal of the International Council of Onomastic Sciences. Vol. 40, 201-211.

Krüger, D. (2005b) Harry Potter's Namenwelt in der Übersetzung. Brylla, E., Wahlberg, M. (Haz.). Proceedings of the 21st International Congress of Onomastic Sciences. Uppsala, August 19-24, 2002 içinde (474-292). Uppsala: Sprakoch Folkminesinstitut 2005.

Krüger, D. (2006). Die literarische Onomastik als Vorstufe der literarischen Übersetzung. Atti del XXII Congresso Internazionale di Scienze Onomastiche. - Bd 3; a cura di Maria Giovanna Arcamone, Pisa, 2006, Il nome nel testo 8, 47-63.

Kurultay, T. (1985). Çeviri Yöntemi Üzerine Düşünceleriyle F.Schleiermacher. Dün ve Bugün Çeviri, 1 (1985), 191-217.

Kurultay, T. (1994). Probleme und Strategien bei der kinderliterarischen Übersetzung im Rahmen der interkulturellen Kommunikation. Ewers, H.-H. , Lehnert, G., O'Sullivan, E. (Haz.). Kinderliteratur im interkulturellen Prozess. Studien zur Allgemeinen und Vergleichenden Literaturwissenschaft içinde (119-201). Stuttgart / Weimar: Metzler Verlag.

Lamping, D. (1983). Der Name in der Erzahlung: zur Poetik des Personennamens. Bonn: Bouvier.

Lietz, G. (1992). Eigennamen in der norwegischen Gegenwartssprache. Probleme ihrer Wiedergabe im Deutschen am Beispiel belletristischer Texte. Frankfurt am Main: Peter Lang Verlag.

Neydim, N. (2003). 80 Sonrası Paradigma Değişimi Açısından Çeviri Çocuk Edebiyatı. İstanbul: Bu Yayınevi, Umut Matbaacilık.

Neydim, N. (2006). Çeviri Çocuk Edebiyatı ve Çocuk Edebiyatı Çevirisi Üzerine. https://ceviribilim.com/2006/06/01/ceviri-cocuk-edebiyati-ve-cocuk-edebiyati-cevirisiuzerine/, erişim 15.01.2021.

Nord, C. (2003). Kommunikativ handeln auf Spanisch und Deutsch. Ein übersetzungsorientierter funktionaler Sprach- und Stilvergleich. Wilhelmsfeld: Gottfried Egert Verlag.

Oitinnen, R. (2000). Translating for children. Londra: Garland Publishing.

Özbent, S. (2017). Almanca edebi eser isimlerinin çevirisinde kültürel etkenler. Uluslararası Bilimsel Araştırmalar Dergisi (IBAD), 611-617. 
Puurtinen, T. (1995). Linguistic acceptability in translated children's literature. Joensuu: University of Joensuu.

Reallexikon der deutschen Literaturwissenschaft (2007). Z. Braungart, G., Fricke, H., Grubmüller, K., Müller, J.-D., Vollhardt, F. \& Weimar, K. (Haz.). Neubearbeitung des Reallexikons der deutschen Literaturgeschichte. Bd. I: $A-G$. Bd. II: $H-O$. Bd III: P içinde (745). Oldenbourg: Walter de Gruyter.

Reiss, K. (1982). Zur Übersetzung von Kinder-und Jugendbüchern. Theorie und Praxis. Lebende Sprachen, 27:1, 1-13.

Schleiermacher, F. (1813/1963). Ueber die verschiedenen Methode des Uebersetzens. Störig, H. J. (Haz.). Das Problem des Übersetzens (=Wege der Forschung 8) içinde (38-69). Darmstadt: Wissenschaftliche Buchgesellschaft.

Seibicke, W. (2008). Die Personennamen im Deutschen. Eine Einführung. Berlin / New York: Walter de Gruyter.

Shavit, Z. (1986). Poetics of Children's Literature. London: The University of Georgia Press.

Sobanski, I. (2000). Die Eigennamen in den Detektivgeschichten Gilbert Keith Chestertons. Ein Beitrag zur Theorie und Praxis literarischer Onomastik. Frankfurt a.M.: Peter Lang Verlag.

Stiegler, B. (1994). Die Aufgabe des Namens. Zur Funktion der Eigennamen in der Literatur des 20. Jahrhunderts. München: Fink.

Thies, H. (1978). Namen im Kontext von Dramen. Studien zur Funktion von Personennamen im englischen, amerikanischen und deutschen Drama. Frankfurt a. M./Bern/Las Vegas: Peter Lang Verlag.

Toury, G. (1995). Descriptive Translation Studies and Beyond. Amsterdam/Philadelphia: John Benjamins Publishing.

Venuti, L. (1995). The Translator's Invisibility: A History of Translation. Londra: Routledge. 